\title{
EXOGENOUS QUERCETIN AS A PROLIFERATION ATIMULATOR IN TOBACCO BY-2 CELLS
}

\author{
Agnieszka Kobylińska \\ Department of Ecophysiology and Plant Development \\ University of Lodz
}

\begin{abstract}
Quercetin (Q) is a prominent flavonoid with a remarkable spectrum of biochemical activities. Its impact on human health as well as its endogenous role in the development of plants have been studied extensively. However, the impact of exogenous quercetin on plant cells is still uncharted. In this study, the influence of exogenous quercetin on Nicotiana tabacum, L. cv Bright Yellow 2 cell growth, viability, morphology and DNA content was investigated. The cells were exposed to quercetin at different concentrations $(0.001,0.01,0.1$ and $1 \mathrm{mM})$ during two phases of cell growth: from the start of a new culture (day 0), that is during the lag phase, when the cells are transferred to a new medium and they adapt to new growth conditions (model A), and on the fourth day after passaging (day 4) during the logarithmic phase of growth (the log phase), when the number of new cells appearing per unit time is proportional to the present population (model B). This is a period of intensive proliferation. The BY-2 cultures were maintained for 8 days. The proliferation level of BY-2 cells as well as their viability were analyzed every day during the experiment. The results showed that quercetin in a dose below $0.1 \mathrm{mM}$ stimulated cell proliferation and viability, thus it could be a promising biostimulator. On the other hand, the highest concentration $(1 \mathrm{mM})$ arrested the cell cycle in G2 phase and led to cell death. Application of $1 \mathrm{mM} \mathrm{Q}$ during the lag phase dramatically increased cell mortality and at the end of the experiment all BY-2 cells were dead, whereas an application during the log phase had a significantly milder effect; under the same concentration only $34 \%$ of cells were dead at the end of the stationary phase of growth. Thus, the results suggest that $\mathrm{Q}$ was less toxic even in very high concentrations when it was added to cells in the log phase of growth. This is probably related to the transfer of cells to a fresh medium, which causes great stress and supplementation with a high concentration of $\mathrm{Q}$ seems to aggravate this stress.
\end{abstract}

Keywords: biostimulator, flavonoid, G2 arrest, Nicotiana tabacum suspension cells, total phenolics.

Agnieszka Kobylińska PhD, Department of Ecophysiology and Plant Development, Faculty of Biology and Environment Protection, University of Lodz, Banacha 12/16, 91-227 Lodz, Poland, phone/fax (+48) 4263544 21, e-mail: akobylin@biol.uni.lodz.pl 


\section{INTRODUCTION}

Quercetin (Q; 3,3, 4, 5,7-pentahydroxyflavone), a plant flavonoid, is a widespread compound in the plant kingdom and occurs naturally in a broad range of fruit and vegetables. Its most important function consists in providing communication with the environment and ensuring plant protection, mainly through its antioxidant action, i.e. protection against photosynthetic stress and reactive oxygen species (ROS), which can damage the cell's DNA. Moreover, Q can chelate transitive metal ions responsible for ROS generation. On the other hand, at high concentrations $\mathrm{Q}$ demonstrates also pro-oxidative features. The presence of flavonoids (including Q) is widespread among plants and plant products (e.g. fermented and processed foods). There has been a growing body of research on the biological properties of $\mathrm{Q}$ and other flavonoids in recent years. These compounds are thought to possess anti-inflammatory, antioxidant, antiviral, anticarcinogenic and antithrombotic activities (MiddletTon et al. 2000; CARRIERI et al. 2013). Quercetin is a secondary metabolite synthesized at a particular stage of plant growth and development and also during biotic and abiotic stresses (YANG et al. 2001). The secondary metabolites (1) participate in the light-dependent phase of photosynthesis, during which they catalyze electron transport (MASTRANGELO et al. 2006), (2) determine the dynamics of carbon metabolism by changing the rates of reducer accumulation and photophosphorylation and also by changing the enzyme activities, (3) low doses of exogenous Q enhance gluconeogenesis and suppress glycolysis resulting in significantly increased monosaccharide content in tomato fruits of various cultivars (StAKHov et al. 2000, STAKHOva et al. 2001).

Plant production technologies based only on the improvement of plants themselves encounter some obstacles due to natural limitations of the biological potential in cultivars. Hence, the constant search for new substances to ensure more favourable conditions for plant growth and development, even by reducing various biological and abiotic stresses, and ultimately to increase yield. The best solution seems to be using biostimulators which are able to provide optimal growth conditions and protection against environmental stress. Biostimulators are natural growth regulators or chemicals. Effects of these components increase physiological activities in plants, first of all protein synthesis. They are also used to protect fruit plants from spring frost damage. They are frequently applied in horticulture. For almost twenty years, it has been known that addition of some well-assimilated nutritive substances is advantageous for plants as it helps them to overcome the herbicide stress. For instance, application of a combination of Aminosol (a blend of amino acids and peptides, referred to as a stress-countering compound) and herbicides for sugar beet is recommended in Germany (Siмtтh 1996). When applied in stressogenic conditions created by abiotic factors (salinity, extreme temperatures, drought, etc.), amino acid mixtures reduce crop losses by stimulating the innate plant defensive responses. 
Numerous studies have demonstrated that flavonoids were able to control the level of plant growth and differentiation. For example, a mixture of phenolic compounds such as the biostimulator Asahi is well documented as an agent raising plant protection against herbicide stress. Thus, the present study has been designed to establish if exogenous $Q$ (naturally occurring in plants, inexpensive and commercially available substance) is able to act as a biostimulator or biofertilizer to increase plant growth and yield. For this research, Nicotiana tabacum L.cv Bright Yellow 2 (BY-2) suspension cells were used. Tobacco BY-2 cells are fast growing plant cells, which are used as model systems for higher plants because of their relatively high homogeneity and high growth rate, yet manifesting the general behaviour of plant cell (NAGATA et al. 1992). The diversity of cell types within any part of an in vivo grown plant makes it very difficult to investigate and understand some general biochemical phenomena of living plant cells. Cell suspension cultures, e.g. tobacco BY-2, are a model plant system comparable to HeLa cells for human research. They provide good model systems for plant physiology and molecular biology studies at the level of a single cell and its compartments because tobacco BY-2 cells behave very similarly to one another (NAGATA et al. 1992).

The objective of this work was to analyze the response of BY-2 cells after treatment with a wide range of $\mathrm{Q}$ concentrations, and the sensitivity of BY-2 cells exposed to this flavonoid depending on their growth phase.

\section{MATERIAL AND METHODS}

BY-2 tobacco cells (Nicotiana tabacum L. cv Bright Yellow 2) were cultivated in Linsmaier and Skoog basal medium (LS) (Linsmaiter, Skoog 1965) supplemented with $87 \mathrm{mM}$ sucrose, $1 \mu \mathrm{M}$ 2,4-dichlorophenoxyacetic acid (2,4-D; synthetic auxin), $3 \mu \mathrm{M}$ thiamine, $0.55 \mathrm{mM}$ myoinositol and $10^{-2} \mathrm{M} \mathrm{KH}_{2} \mathrm{PO}_{4}$. The initial $\mathrm{pH}$ of the medium was established as 5.3.

BY-2 cell cultures at the stationary growth phase were passaged into a fresh LS medium as a control and LS with $\mathrm{Q}$ with the final concentration in media: $0.001 \mathrm{mM}, 0.01 \mathrm{mM}, 0.1 \mathrm{mM}$, and $1 \mathrm{mM}$.

Quercetin was added during two phases of cell growth:

model $\mathrm{A}-\mathrm{Q}$ was added from the start of a new culture (day 0) - during the lag phase when plant cells adapt themselves to growth conditions. During the lag phase, synthesis of RNA, enzymes and other molecules occurs.

model $\mathrm{B}-\mathrm{Q}$ was added on the fourth day after passaging (day 4) during the logarithmic phase of growth (the log phase), when the number of new cells appearing per unit time is proportional to the present population. During this phase, the growth of cells is not limited. 
The flasks were kept on a rotary shaker, $100 \mathrm{rpm}$, at $24^{\circ} \mathrm{C}$ in darkness. The experiments were continued for 8 days.

The cell number was determined with the use of a Fuchs-Rosenthal haemocytometer under a light microscope; additionally the number of dead cells was assessed after selective staining with methylene blue. The number of cells and their viability were analyzed every experimental day. The morphology, total phenolics concentration and DNA content were analyzed at the end of the $\log$ phase, i.e. on the $6^{\text {th }}$ day.

Morphology of the control and $\mathrm{Q}$ treated cells was examined under an Olimpus CX-31 light microscope equipped with a MicroScan v.15. digital system of image analysis. To detect the morphological changes in the Q-exposed cells versus the control ones, the methylene blue staining method was used. Living cells do not take up the stain and retain their natural colour whereas damaged cells are stained blue as they are unable to keep methylene blue from penetrating their membranes.

Phenolic compounds were extracted with pure methanol from the control and $\mathrm{Q}$ treated cells, at the end of the $\log$ phase of growth, i.e. on the $6^{\text {th }}$ day of experiment. After centrifugation (1500 x g, $10 \mathrm{~min})$, the control and Q exposed BY-2 suspension cultures were re-suspended in methanol $(10 \mathrm{ml}$ methanol/ $0.2 \mathrm{~g}$ cells) and kept in darkness for $24 \mathrm{~h}$ on a rotary shaker 100 rpm at room temperature.

After the next centrifugation (1500 x g, $10 \mathrm{~min}$ ), the supernatants were collected. The total phenolic content was estimated by the Folin-Ciocalteu method using gallic acid as a standard (SLincard, Singleton 1977). $50 \mu \mathrm{l}$ of the extract were combined with $1.55 \mathrm{ml}$ of distilled water, $100 \mu \mathrm{l}$ of Folin-Ciocalteu's reagent and $300 \mu \mathrm{l}$ of $20 \% \mathrm{Na}_{2} \mathrm{CO}_{3}$. The mixture was vortexed thoroughly and, after incubation at $40^{\circ} \mathrm{C}$ for $30 \mathrm{~min}$, the absorbance was measured at $765 \mathrm{~nm}$ against a 'blank' without the sample extract. Quantification was done on the basis of the standard curve of gallic acid (solution $0.25-5 \mu \mathrm{g} \mathrm{ml}^{-1}$ ). The results were expressed as mg of gallic acid equivalents (GAE) per $\mathrm{g}$ of cells.

The control and Q exposed BY-2 cells from the end of the log phase $\left(6^{\text {th }}\right.$ day of growth) in model B were fixed in cold 3:1 absolute alcohol/glacial acetic acid mixture (Carnoy solution) for 1h, washed and kept in 70\% ethanol. The choice of model B was dictated by the fact that at the end of the $\log$ phase in model A the cells treated with the highest concentration of $\mathrm{Q}$ were mostly dead. The samples were hydrolyzed in $4 \mathrm{~N} \mathrm{HCl}$ for $1 \mathrm{~h}$ at room temperature and stained with Schiff's reagent (prepared from basic fuchsine) for $1 \mathrm{~h}$ for cytophotometric estimation of $2 \mathrm{C}, 2-4 \mathrm{C}$ and $4 \mathrm{C}$ nuclear DNA contents. The stained cells were washed three times in water for $10 \mathrm{~min}$ each and dried briefly on absorbent paper. Dark-stained cells were smeared in a drop of acetic acid and left on dry ice for $15 \mathrm{~min}$. Then, the cells were washed in $70 \%$ ethanol and embedded in Canada Balsam. Scoring was done from 5 different samples of randomly selected 100 nuclei each, using a MicroScan v5 cytophotometer set at a wavelength of $555 \mathrm{~nm}$. On average, 20 prophase and 
20 telophase nuclei were measured in each of five replicates of the control and all experimental samples.

The data represent the means \pm standard deviation $( \pm \mathrm{SD})$. Each variant of culture was replicated 5 times and three independent samples were used for measurements. The significance of differences between mean values was compared by Student's $t$-test with $P<0.05$.

\section{RESULTS AND DISCUSSION}

It has been reported that flavonoids (including Q) function in the plant kingdom as UV protectants, pollinator attractants and antimicrobial compounds. Although flavonoids are a large group of polyphenolic compounds found in fruit and vegetables, their exogenous influence on plant cells and mechanism of their action have still not been identified. As it has already been reported, $\mathrm{Q}$ has a protective role against chromosome aberrations induced by herbicides (MASTRANGELO et al. 2006). The recent data have shown that phenol derivatives act as active biostimulators for a broad spectrum of plants, for example the commercially available biostimulator Asahi consists of nitrophenols, which occur naturally in plants.

The present study has been designed to assessed if exogenous $Q$ is able to act as an effective biostimulator to increase plant growth and yield.

The influence of $\mathrm{Q}$ on the growth of BY-2 suspension culture was analyzed in two models: from the start of a new culture, that is in the lag phase (model A), and in the log phase of growth (model B). These models were chosen to check the sensitivity of suspension cells in different phases of their growth. The cultures exposed to $\mathrm{Q}$ at different concentrations $(0.001-1 \mathrm{mM})$ were compared with the non-treated - control ones. The greatest differences between both models were noted in the log phase of growth. The results revealed that at the end of the log phase of culture (day 6) the low concentrations $(0.001 \mathrm{mM}$ and $0.01 \mathrm{mM})$ of $\mathrm{Q}$ applied in model $\mathrm{A}$ increased the cell number versus the control by $3 \%$ and $5 \%$ respectively, whereas the high concentrations $(0.1 \mathrm{mM}$ and $1 \mathrm{mM})$ of this flavonoid inhibited cell proliferation and on day 6 the numbers of cells were by $70 \%$ and $96 \%$ lower than in the control for $0.1 \mathrm{mM}$ and $1 \mathrm{mM}$ respectively (Figure $1 a$ ). In model $\mathrm{B}$, when the low doses of $\mathrm{Q}$ were added in the $\log$ phase of cell growth, they stimulated the plant growth. After an application of $0.001 \mathrm{mM}$ and $0.01 \mathrm{mM} \mathrm{Q}$, at the end of the log phase (day 6) the counts of BY-2 cells were higher than in the control by $19 \%$ and $30 \%$ respectively.

Quercetin changed the cycle of culture growth in the phase-of-growthand concentration-dependent manner. In model A, when tobacco cells where treated with $0.1 \mathrm{mM}$ and $1 \mathrm{mM}$ concentrations, a characteristic curve of cell growth disappeared. The former dose eliminated both typical log and stationary 

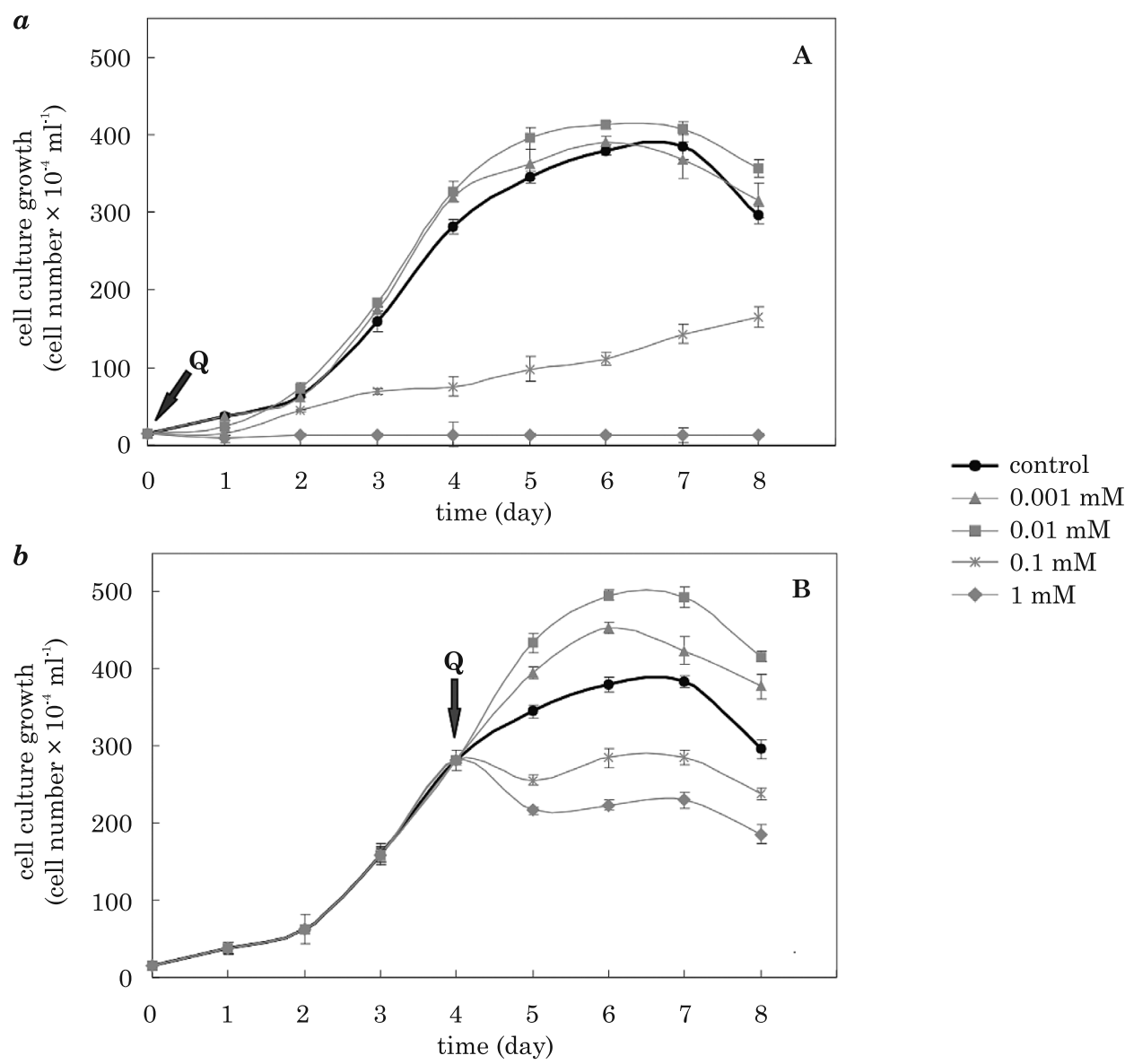

Fig. 1. BY-2 cell culture growth rate after exposure to: 0 (control), 0.001, 0.01, 0.1 and $1 \mathrm{mM}$ of quercetin. $\mathbf{Q}$ was added according to two models: $\mathbf{A}$ - from the start of a new culture

(day 0) - during the lag phase; $\mathbf{B}$ - on the fourth day after passaging (day 4) - in the log phase of growth; $\mathbf{Q}$ - time of quercetin application. Studies were performed for 8 days.

Each value is the mean $\pm \mathrm{SD}(n=5)$

phases, whereas the latter was lethal (Figure 1a). In model B (Figure 1b), the same concentrations accelerated the beginning of the stationary phase and made it longer than in the control. Unfortunately, similarly to the model A, a decreased cell number was observed in the presence of the highest concentration of Q (Figure $1 a, b$ ).

Positive results were obtained when $\mathrm{Q}$ was applied in low doses. On day 8, when the untreated cells finished the stationary phase and started the death phase, the number of cells after Q treatment at concentrations below $0.1 \mathrm{mM}$ was significantly higher: by about $10 \%$ and $20 \%$ in model A, and by $30 \%$ and $40 \%$ in model B versus the control for $0.001 \mathrm{mM}$ and $0.01 \mathrm{mM}$, respectively (Figure 1a,b). 
The effect of Q on the BY-2 cell culture viability was also investigated. Dead cells were analyzed every experimental day during the 8-day culture after selective staining with methylene blue.

In the control - throughout the period of cell growth - a gradual increase in the dead cell count was observed. It was especially visible in the stationary phase of growth, which is a physiological stage of cell growth due to the consumption of nutrients. At the end of culture, $23 \%$ of cells were dead (Figure $2 a, b)$. The low doses of $\mathrm{Q}(0.001 \mathrm{mM}$ and $0.01 \mathrm{mM})$ seemed to act not only as a proliferation stimulator but also a pro-survival agent. The cell mortality at the end of the experiment was lower by $5-25 \%$ (in model A) or even by $70 \%$ (in model B) compared to the control. The sensitivity of BY-2 cells was much higher in model A then in B. This is probably related to the

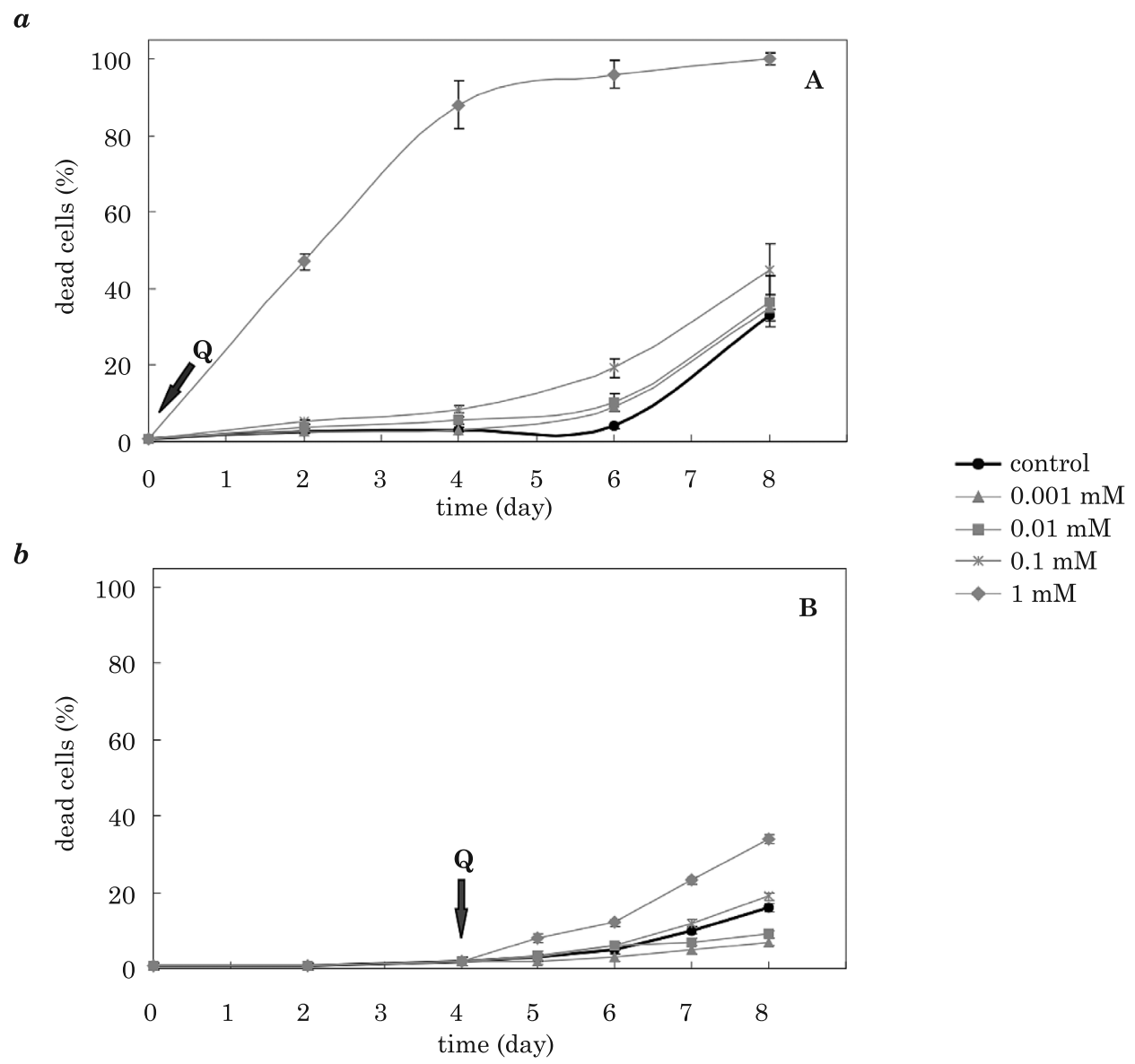

Fig. 2. Mortality of BY-2 cell treated with: 0 (control), 0.001, 0.01, 0.1 and $1 \mathrm{mM}$ of quercetin after selective staining with methylene blue. $\mathrm{Q}$ was added according to two models:

A - from the start of a new culture (day 0) - during the lag phase; $\mathbf{B}$ - on the fourth day after passaging (day 4) - in the log phase of growth; $\mathbf{Q}$ - time of quercetin application. Studies were performed for 8 days. Each value is the mean $\pm \operatorname{SD}(n=5)$ 
transfer of cells to a fresh medium (in model A), which causes great stress and supplementation with the high concentration of $\mathrm{Q}$ seems to exacerbate this stress.

Similar results were obtained for the human K562 erythroleukemia cell line (Csokay et al. 1997). Csocay et al. (1997) showed that in K562 cells 0.55 and $5 \mu \mathrm{M} \mathrm{Q}$ concentrations induced differentiation whereas higher concentrations, such as 55 and $550 \mu \mathrm{M}$, exerted opposite effects and cells were undergoing programmed cell death (PCD). Ambiguous results were also obtained for glioblastoma cells treated with $\mathrm{Q}$ and isoquercitrin; low concentrations enhanced cell proliferation whereas $0.1 \mathrm{mM}$ resulted in time -dependent inhibition of cell proliferation (AMADO et al. 2009).

The present results clearly show that $\mathrm{Q}$ at low doses stimulated proliferation of plant cells, but concentrations higher than $0.1 \mathrm{mM}$ blocked cell division. The experimental data indicated that toxicity of high concentrations of $\mathrm{Q}$ depended on the phase of cell growth in which they were treated, thus tobacco BY-2 cells seemed to have considerably greater resistance to a high concentration of $\mathrm{Q}$ when it was applied during the log phase of growth.

Quercetin in low doses may also prevent oxidative stress in plants. This flavonoid was found in exudates of Haplopappus multifolius and it could account for the protection of these plants against oxidative stress (ToRREs et al. 2006). The protective role of $Q$ against oxidative stress was also analyzed in ethanol-induced gastric mucosal lesion. In that study, Q reduced lipid peroxidation and increased the activity of antioxidant enzymes.

However, the action of $\mathrm{Q}$ is complex and paradoxical. The influence of $\mathrm{Q}$ on enzymes associated with oxidative stress was observed during cucumber mosaic virus (CMV) infection of Nicotiana megalosiphon host plants. RIEDLE -BAUER (2000) observed enhanced peroxidase activities in CMV-infected $\mathrm{Cu}$ cumis sativus plants, whereas RUSAK et al. (2007) demonstrated significantly decreased total peroxidase activities in Q-treated infected plants. Similar results were shown in human cervical cancer, osteosarcoma and liver hepatocellular carcinoma cells, where Q-induced decrease in cell viability was accompanied with an induction of apoptosis (PRIJADARSINI et al. 2010, SuH et al. 2010).

Quercetin-triggered cell death was connected with a rapid reduction of inositol-1,4,5-trisphosphate and decrease in $c$-myc and $K i$-ras oncogenes, which were overexpressed in K562 cells (CsokAY et al. 1997). Moreover, the induction of apoptosis after an application of $Q$ triggers changes in the expression of proteins involved in the apoptosis program, such as a significant decrease in the expression of survivin, Bcl-2, Bcl-xL, Mcl-1, p-Bad and mitochondrial cytochrome $\mathrm{c}$ in cells treated with $\mathrm{Q}$ as compared to the untreated control. Moreover, under the same conditions, a considerable increase in the expression of Bax, Bad, cytosolic cytochrome c, Apaf-1, caspase -9 and -3, and PARP cleavage was noted (PRIJADARsini et al. 2010, Niu et al. 2011).

Our studies revealed that exogenous $\mathrm{Q}$ had ambiguous effects on plant 
cells. It could be an effective biostimulator but in excessive doses it significantly decreased both proliferation and viability of BY-2 cell. Under the highest concentration, many morphological changes appeared in BY-2 cells: shrunken cells with nuclei irregular in shape and constricted cytoplasm were observed. The plasma membrane moved away from the cell wall leaving visible space (Figure 3). The microscopic picture of the cells treated with the
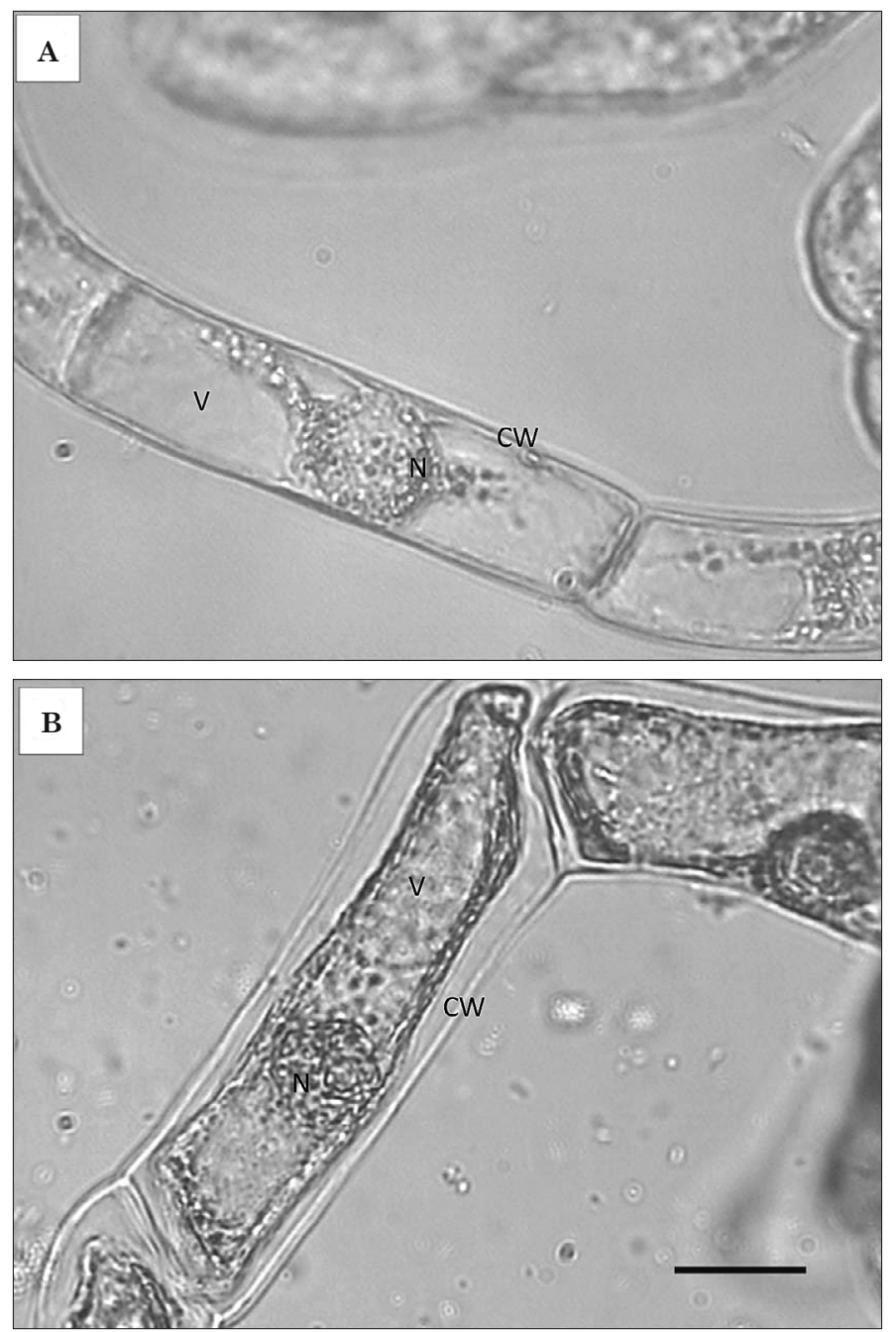

Fig. 3. Morphological alterations of tobacco BY-2 cells stained with methylene blue: A - untreated (control) cells, B - morphology of BY-2 cells treated with $1 \mathrm{mM}$ of quercetin. The 6 -day-old cells were stained with methylene blue and photographed under light microscopy. Bar $=15 \mu \mathrm{m}, \mathrm{N}-$ nucleus, $\mathrm{CW}-$ cell wall, $\mathrm{V}-$ vacuole 
high doses of $\mathrm{Q}$ seemed to be similar to those presented in the literature focusing on the changes of morphology in BY-2 cells undergoing PCD (VACCA et al. 2004, HuAng et al. 2009), although they should be supplemented with molecular and biochemical markers of PCD. These observations showed that high concentrations of $\mathrm{Q}$ were toxic and induced changes in cells' morphology.

Quercetin plays an important protective role against stress factors. In Arabidopsis with overexpression of PAP1 gene (Production of Anthocyanin Pigments 1), a higher synthesis of quercetin 3-O-glucoside, a strong antioxidant, was observed alomgside an inhibited synthesis of kaemferol 3-O-glucoside, which is a weaker antioxidant (Torres et al. 2006). Thus, the accumulation of antioxidant agents can play a key role in understanding why at the same concentrations of Q, BY-2 cells' viability was different and depended on the phase of cell growth. It is important to find out at which point of a cell culture $\mathrm{Q}$ should be added to be non-toxic. Plants have evolved a complex array of non-enzymatic and enzymatic detoxification mechanisms to protect themselves from oxidative damage. In this area, phenolic compounds may play an important role as scavengers of free radicals and other oxidative species (TorRes et al. 2006).

In plants, flavonoids have been shown to localize to different cell compartments, indicating multiple physiological roles. Subcellular sites of flavonoid accumulation include the nucleus, where some of the biosynthetic enzymes are also found. These findings are consistent with the idea that some flavonoids could exert direct control on the transcription of genes involved in plant growth and development. BEssEAu et al. (2007) revealed that flavonoid accumulation in Arabidopsis repressed plant growth, but there are no data showing how exogenous $\mathrm{Q}$ may affect intracellular polyphenol levels. Polyphenols are micronutrients abundant in our diet and there are many studies on their bioavailability and bio-efficacy in humans. There is some evidence that $\mathrm{Q}$ is rapidly metabolized and does not accumulate in human cells, but there are no similar data for plants (YANG et al. 2006).

The total phenolics content in the extracts of the untreated and $0.001-1 \mathrm{mM}$ Q treated BY-2 cells was assessed. Quercetin concentrations ranging from 0.001 to $0.1 \mathrm{mM}$ did not considerably change the total phenolic level, regardless of the phase-of-growth, as the results for both phases were comparable. However, the highest concentration of $\mathrm{Q}(1 \mathrm{mM})$ caused significant differences in the phenolic level depending on the phase of growth of tobacco suspension cells $(P<0.05)$. Our analyses demonstrated that the accumulation of total phenolics was over double in model $\mathrm{A}$ and nearly triple in model $\mathrm{B}$ than in the control. These data indicate that the amount of total phenolics depended on the phase of growth of BY-2 suspended cells and it was correlated with the sensitivity of exposed cells (Figure 4). It has been hypothesized that high doses of exogenous $\mathrm{Q}$ are the cause of cell stresses, which is demonstrated by an increase in the total phenolic level. According to BesseAU et al. (2007), inhibition of plant growth resulting from accumulation of flavo- 

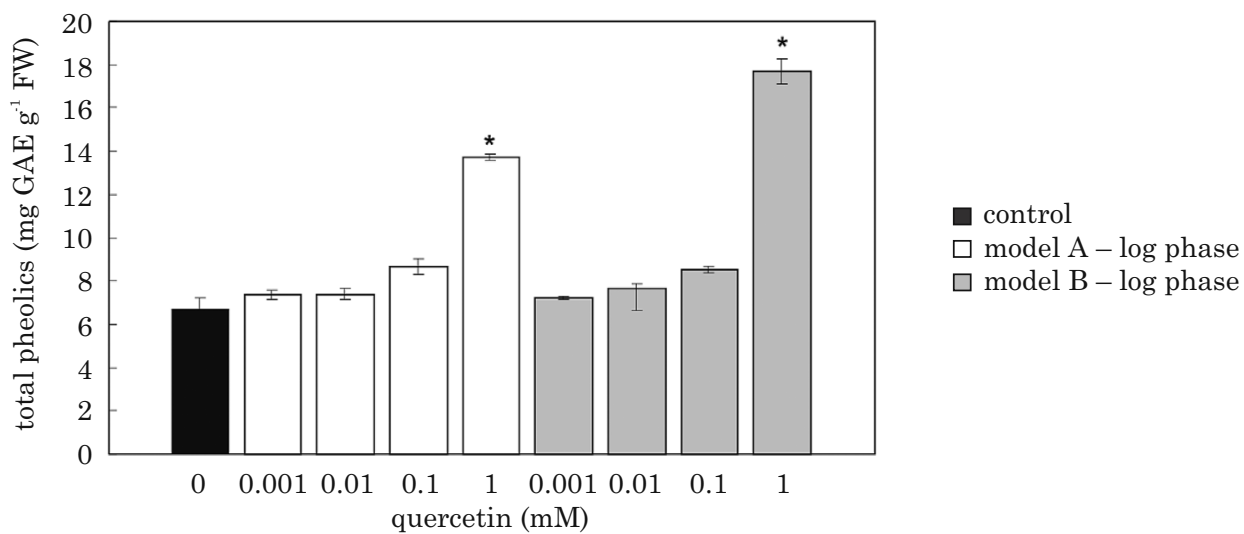

Fig. 4. Total phenolic content in tobacco BY-2 cells treated with: 0 (control), 0.001, 0.01, 0.1 and $1 \mathrm{mM}$ of quercetin. $\mathrm{Q}$ was added according to two models: $\mathbf{A}$ - from the start of a new culture (day 0) - during the lag phase; $\mathbf{B}$ - on the fourth day after passaging (day 4) - in the $\log$ phase of growth. Analyses were performed at the end of the $\log$ phase - the $6^{\text {th }}$ day of experiment. Each value is the mean $\pm \mathrm{SD}(n=3)$

noids may be connected with some blockade of auxin transport. However, accumulation of phenolic compounds in the cells treated with the highest concentration of $\mathrm{Q}$ was probably their response to the increase in ROS and the reason for the repressed plant growth. Interestingly, the amount of total phenolics was 30\% higher when the $\mathrm{Q}$ exposition started from the logarithmic phase of growth. This may be explained by the fact that cells exposed to the highest dose of $\mathrm{Q}$ in model $\mathrm{A}$ were mostly dead in the examined time. It may have resulted in an increased cell wall permeability and leakage of the cell contents to the culture medium.

Quercetin is a bioactive plant flavonoid which is able to inhibit cell proliferation in several cancer cells. Investigations into molecular mechanisms underlying the inhibition of cell proliferation showed that treatment with $Q$ could arrest the cell cycle at G1/S and/or G2/M phase transition and subsequently activate caspase cascade and apoptosis (SuH et al. 2010).

The DNA content in the nuclei of untreated and Q-treated BY-2 cells was only in model B investigated (model A was excluded from analyses because most cells in model $\mathrm{A}$ at the examined time of culture were dead). The comparison of the DNA content in the telophase (2C) and prophase (4C) of BY-2 cells in the control and in the Q-exposed material showed that the highest of the selected concentrations $(1 \mathrm{mM})$ induced cell cycle arrest in G2 phase, an event which was accompanied with a nearly five-fold increase in the frequency of $4 \mathrm{C}$ DNA nuclei. However, the presence of $\mathrm{Q}$ in the culture medium in doses below $0.1 \mathrm{mM}$ did not cause significant changes of the DNA content (Figure 5). Literature data point to similar effects observed in different cancer lines. It was documented that $\mathrm{Q}$ inhibited cell proliferation through a cell cycle arrest at G2/M phase in NCI-H209, K-562, HepG2 and HeLa cells (Manach et al. 2005, PriJadarsini et al. 2010, Niu et al. 2011). 

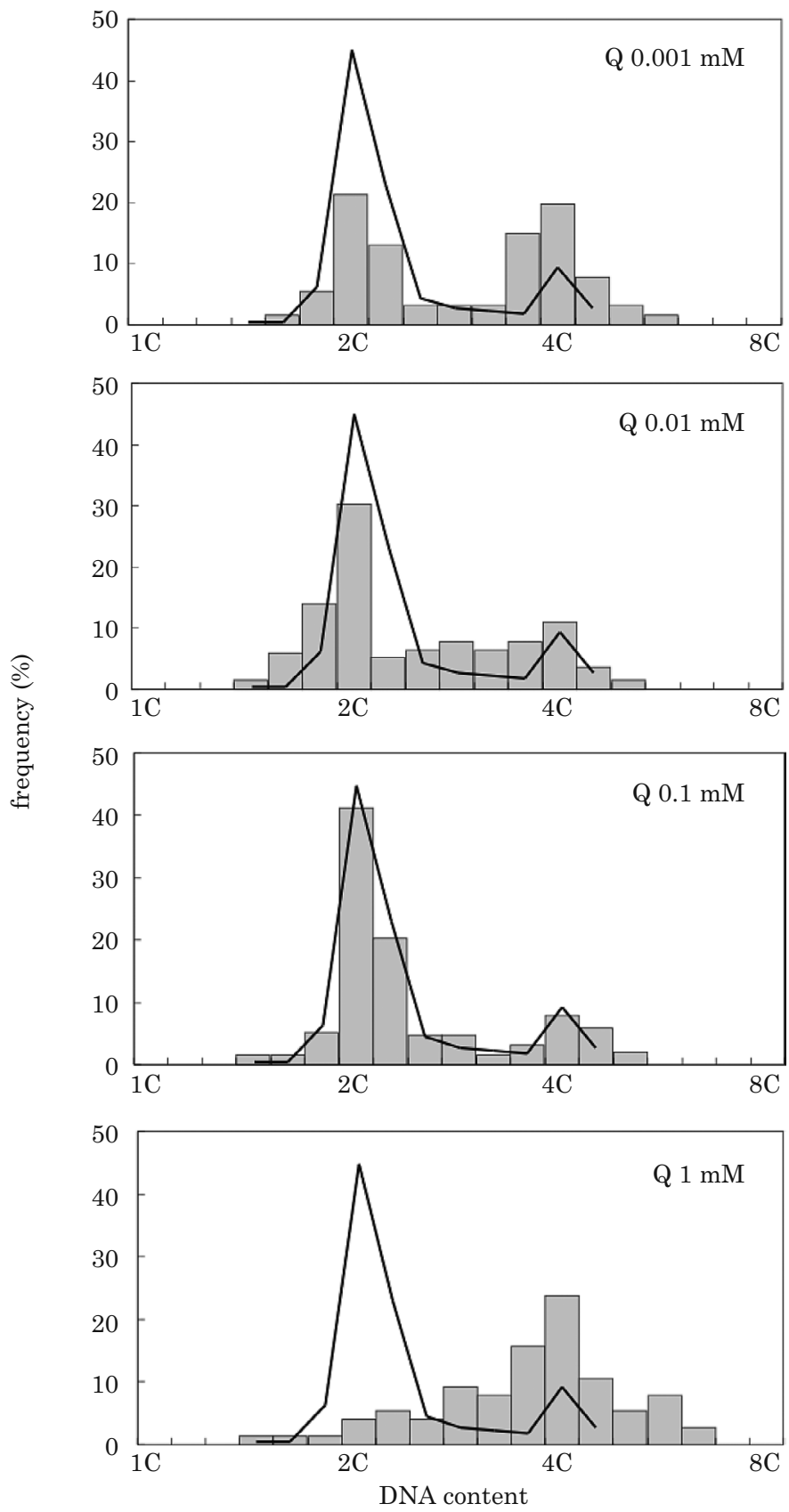

Fig. 5. DNA content in nuclei of BY-2 cells. Line graph - untreated (control) cells, bar graph - cells treated with: 0.001, 0.01, 0.1 and $1 \mathrm{mM}$ of Q. Quercetin was added on the fourth day after passaging (day 4) - in the log phase of growth. Analysis was performed at the end of the $\log$ phase - the $6^{\text {th }}$ day of experiment 


\section{CONCLUSIONS}

It can be concluded that at low concentrations (especially at $0.01 \mathrm{mM}$ ) $\mathrm{Q}$ acts as a biostimulator and great inducer of cell division as well as a pro -survival agent in a phase-of-growth-dependent manner. The highest dose $(1 \mathrm{mM})$ arrests the cell cycle in G2 phase and destroys BY-2 cells.

\section{ACKNOWLEDGMENTS}

I would like to thank Prof. Małgorzata Posmyk from the Department of Ecophysiology and Plant Development for her help in revising this manuscript, and Aneta Domańska from the Department of Plant Cytology and Cytochemistry for analyses of the DNA content.

\section{REFERENCES}

Amado N.G., Cerqueira D.M., Menezes F.S. 2009. Isoquercitrin isolated from Hyptis fasciculata reduces glioblastoma cell proliferation and changes beta-catenin cellular localization. Anticancer Drug., 20: 543-552.

Besseau S., Hoffmann L., Geoffroy P. 2007. Flavonoid accumulation in arabidopsis repressed in lignin synthesis affects auxin transport and plant growth. The Plant Cell., 19: 148-162.

Carrieri C., Milella R.A., Incampo F. 2013. Antithrombotic activity of 12 table grape varieties. Relationship with polyphenolic profile. Food Chem., 140:647-653.

Csokay B., Prajda N., Weber G. 1997. Molecular mechanisms in the antiproliferative action of quercetin. Life Sci., 60: 2157-2163.

Huang W., Xing W., Li D. 2009. Morphological and ultrastructural changes in tobacco BY-2 cells exposed to microcystin-RR. Chemosphere, 76: 1006-1012.

Linsmaier E.M., Skoog F. 1965. Organic growth factor requirements of tobacco tissue cultures. Physiol Plant, 18: 100-127.

Manach C., Williamson G., Morand C. 2000. Bioavailability and bioefficacy of polyphenols in humans. I. Review of 97 bioavailability studies. Am. J. Clin. Nutr., 81:230-242.

Mastrangelo S., Tomassetti M., Caratu M.R. 2006. Quercetin reduces chromosome aberrations induced by atrazine in the allium cepa test. Environ. Mol. Mutagen., 47: 254-259.

Middletton E .JR., Kandaswami C., Theoharides T.C. 2000. The effects of plan flavonoids on mammalian cells: implication for inflammation, heart disease, and cancer. Pharmacol. Rev., 52: 673-751.

Nagata T., Nemoto Y., Hasezawa S. 1992. Tobacco BY-2 cell line as the "HeLa" cell in the cell biology of higher plants. Int. Rev. Cytol., 132: 1-30.

NiU G., YIN S., XIE S. 2011. Quercetin induced apoptosis by activating caspase-3 and regulating Bcl-2 and cyclooxygenase-2 pathways in human HL-60 cells. Acta Biochim. Biophys., 43: 30-37.

Priyadarsini R.V., Murugan R.S., Maitreyi S. 2010. The flavonoid quercetin induces cell cycle arrest and mitochondria-mediated apoptosis in human cervical cancer (HeLa) cells through p53 induction and NF-кB inhibition. Eur. J. Pharmacol., 649: 84-91.

Riedle-BAuer M. 2000. Role of reactive oxygen species and antioxidant enzymes in systemic virus infections of plants. J. Phytopathol., 148: 297-302.

Rusak G., Kraja M., Krsnik-Rasol M. 2007. Quercetin influences response in Nicotiana megalosiphon infected by satellite-associated cucumber mosaic virus. J. Plant Dis. Protect., 114:145-150. 
Siмeтн G. 1996. Umweltgerechte Unkrautregulierung mit reduzierten Aufwandmengen. Deutsche Zuckerrübenzeitung, 32: 8-9.

Slincard K., Singleton V.L. 1977. Total phenol analysis: Automation and comparison with manual methods. Am. J. Enol. Viticult., 28: 49-55.

Stakhov L.F., Stakhova L.N., Ladygin V.G. 2000. Effect of exogenous quercetin on the levels of carbohydrates and amino acids I fruits of Lycopersicon esculentum. Appl. Biochem. Microbiol., 36: 197-200.

Stakhova L.N., Ladygin V.G., Stakhov L.F. 2001. Changes in the content of sugars and amino acid in the fruit of Lycopersicon esculentum after quercetin treatment. Biol. Bull., 28: 471-476.

Suh D.K., Lee E.J., Kim H.C. 2010. Induction of $G_{1} / S$ phase arrest and apoptosis by quercetin in human osteosarcoma cells. Arch. Pharm. Res., 33: 781-785.

Torres R., Faini F., Modak B. 2006. Antioxidant activity of coumarins and flavonols from the resinous exudate of Haplopappus multifolius. Phytochemistry, 67: 984-987.

Vacca R.A., de Pinto M.C., Valenti D. 2004. Production of reactive oxygen species, alteration of cytosolic ascorbate peroxidase, and impairment of mitochondrial metabolism are early events in heat shock-induced programmed cell death in tobacco Bright-Yellow 2 cells. Plant Physiol., 134:1100-1112.

YANG C.S., Landau J.M., Huang M.T. 2001. Inhibition of carcinogenesis by dietary polyphenolic compounds. Annu. Rev. Nutr., 21: 381-406.

YANG J.H., Hsia T.C., Kuo H.M. 2006. Inhibition of lung cancer cell growth by quercetin glucuronides via G2/M arrest and induction of apoptosis. Drug Metab. Dispos., 34: 296-304. 